\title{
Securing Orders as a Tool in the Fight against Tax Evasion: Czech Republic Case Study
}

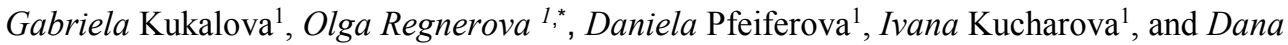 \\ Mejstrikova $^{1}$ \\ ${ }^{1}$ Czech University of Life Sciences, Faculty of Economics and Management, Department of Trade \\ and Finance, Kamycka 129, 16500 Praha 6 - Suchdol, Czech Republic
}

\begin{abstract}
.
Research background: Combating tax evasion is part of tax administration in most countries. As globalization progresses, tax evasion and tax fraud are growing. All this has a negative impact on tax revenues of state budgets. Globalization is helping to apply similar practices by states against tax evasion. Within the EU, it is mainly about harmonization and common procedures for VAT. Revenues from VAT are a significant revenue of the state budget also in the Czech Republic, therefore various tools are used in the constant fight against VAT fraud.

Purpose of the article: The aim of the article is to evaluate the effectiveness of securing orders in the fight against VAT fraud in the Czech Republic.

Methods: Data for the monitored period 2014 - 2018 were obtained from documents of the Financial Administration of the Czech Republic. The analysis of securing orders and the estimation of the costs of their issuance is performed based on the stated data. Subsequently, the effectiveness of issued securing orders in the monitored period is evaluated.

Findings \& Value added: In the context of globalization, a number of studies deal mainly with the causes and effects of tax arrears, tax evasion and the tax gap. This paper discusses the fight against tax evasion, focusing on a specific instrument - securing orders. Based on the analyzes, an estimate is made of the costs of issuing securing orders. Subsequently, the effectiveness of securing orders is evaluated as one of the instruments in the fight against VAT fraud.
\end{abstract}

Keywords: tax; securing order; tax evasion; value added tax; VAT fraud

JEL Classification: $H 20 ; H 26 ; H 30$

\footnotetext{
${ }^{*}$ Corresponding author: oregnerova@pef.czu.cz
} 


\section{Introduction}

From the point of view of the globalized economy, taxes are among the main sources of the revenue side of state budgets. These resources are used to cover public expenditure. Therefore, the tax policy is essential for the economic policies of each country. The issue of financing public budget expenditures is very topical, especially in connection with the mitigation of the consequences of COVID 19. With the level of globalization, both macroeconomic and microeconomic changes have a nearly immediate impact on individuals. Moral concerns are also gaining global recognition [1].

Illegal acts against tax laws are considered tax evasion, but also a reduction of the tax burden by legal acts. There are (therefore) a number of reasons why tax evasion represents a reduction in state budget revenue. They also have a major negative impact on the principle of voluntary payment of taxes by tax entities. One of the forms of tax evasion is also aggressive tax planning, which also causes a decline in the revenue side of the state budget [2]. Authors [3] dealt with the issue of motivating tax subjects to comply with tax regulations in his research. According to this research, the reasons for motivation are mainly financial (audits, fines). But they can also be non-financial in nature (empathy, compassion, morality). As reported by [4], the introduction of a specific measure against the reduction of one variant of tax evasion may give rise to alternative ways of reducing tax liability. The authors addressed the specific response of US taxpayers following the introduction of the Foreign Account Tax Compliance Act (FATCA). According to [5], the tax entity that decides to reduce taxes thus compares its benefit from this activity with the probability of detection and the amount of the impending sanction. In his paper [5] analyzes the factors that influence the growth of tax evasion and the occurrence of tax arrears, which include, for example, the VAT rate, tax morale, legal efficiency and the level of corruption in society. According to [6], the amount of loss of public budgets caused by tax evasion cannot be precisely quantified in most countries. As the author further states, data on the size of tax evasion are often only expert estimates based on the experience of their authors. Some authors [7] also point out in their article, which deals with tax evasion in Turkey, the difficulty of detecting them using statistical analyzes. The reason for the existence of tax evasion is seen by [8] in the excessive fiscal pressure exerted on taxpayers. In their paper, the authors analyzed the impact of corruption and the gray economy in six countries in Southeast Europe.

A specific impact on business relations from the point of view of VAT and on how to influence the amount of tax paid to the state budget is that the businessman (VAT payer) is interested in entering into supplier relations only with other VAT payers. This is precisely so that he can apply input VAT and thus reduce his tax liability to the state. In the article Hoseini [9] describes this property as a "self-enforcing" property and thoroughly examines in the links between VAT payers, VAT, non-VAT payers and the impact on economic sectors.

. The key tax revenue for EU funding is value added tax. It is therefore important that individual Member States cooperate in exchanging information. In addition to VAT, direct and excise taxes are also an important revenue of state budgets, which are used to obtain resources for investments [10]. VAT fraud leads to significant distortions of the internal market, creates unfair competition and leads to a shortfall in tax revenue not only in individual Member States, but can also distort Member States' contributions to the EU budget [11]. The Commission of the European Union has set VAT as one of the conditions for membership in the European Union.

In the Czech Republic, the financial administration uses general procedures in the administration of taxes, in particular tax control, local investigation, the procedure for removing doubts, search activities and explanations. Furthermore, according to [12], it can 
also use a securing order and control report to effectively detect tax evasion. From 1 January 2016, VAT payers in the Czech Republic became legally obliged to submit the socalled control report, which it regulates [13]. The control report is based on the records for VAT tax purposes, which VAT payers are obliged to keep for the purposes of compiling the tax return [12].

A securing order is one of the institutes of financial administration that can block the assets of companies suspected of non-payment of tax. Officials can collect the estimated tax in advance, withholding money or property until the company has paid the amount stated in the order. According to [14], the core of the securing order is the ability of the tax administrator to secure the tax that has not yet been paid by imposing an obligation on the tax subject to pay the securing to the tax administrator. It is due at the moment of execution of the securing order. The tax administrator may issue a detention order at a time when the exact and justified tax liability is not yet known, ie at the time of issuing the securing order, the tax administrator has not yet issued a decision quantifying the tax liability.

As [15] points out, a detention order can be an effective tool in the fight against tax fraud. Furthermore, it can be a relatively drastic restrictive measure that can have a significant impact on the assets of taxable persons and, in some cases, on their very existence. Therefore, according to the author, its use is inappropriate if this suspicion does not exist. In the analysis of the effectiveness of the measures introduced against tax evasion in carousel fraud, the authors [16] state that of all the measures introduced by the Czech government, the tightening of the rules for unreliable payers introduced since 2013 had the greatest positive impact. On the other hand, this analysis did not confirm the view that securing orders increase VAT revenue.

In the context of globalization, a few studies deal mainly with the causes and effects of tax arrears, tax evasion and the tax gap. This paper discusses the fight against tax evasion, focusing on a specific instrument - securing orders. The aim of the article is to evaluate the effectiveness of securing orders in the fight against VAT fraud in the Czech Republic.

\section{Data and Methods}

Data for the monitored period 2014-2018 were obtained from documents of the Financial Administration of the Czech Republic. These are data obtained on the number of VAT payers and the number of entities affected by the securing order. The analyses are also based on data on VAT revenue, the amount of the secured amount and the amount of reinsurance payments (Table 1).

Table 1. Basic data for the analysis of securing orders, Financial Administration of the Czech Republic (2020).

\begin{tabular}{|c|c|c|c|c|c|}
\hline & $\mathbf{2 0 1 4}$ & $\mathbf{2 0 1 5}$ & $\mathbf{2 0 1 6}$ & $\mathbf{2 0 1 7}$ & $\mathbf{2 0 1 8}$ \\
\hline Number of VAT payers & 512,034 & 506,309 & 503,145 & 522,266 & 535,507 \\
\hline VAT collection (billion CZK) & 322.70 & 331.60 & 349.46 & 381.44 & 413.01 \\
\hline Number of issued securing orders & 1,032 & 1,605 & 1,561 & 1,420 & 1,174 \\
\hline $\begin{array}{c}\text { Number of entities affected by the } \\
\text { securing order }\end{array}$ & 328 & 424 & 309 & 358 & 355 \\
\hline Amount secured (billion CZK) & 4.172 & 3.633 & 3.329 & 1.594 & 1.472 \\
\hline $\begin{array}{c}\text { Amount of payments from securing } \\
\text { orders (billion CZK) }\end{array}$ & 0.256 & 0.822 & 1.098 & 0.690 & 0.471 \\
\hline
\end{tabular}

Analysis of the number of issued securing orders in relation to the number of tax entities affected by the securing order are performed on the basis of these data. The result of the analysis is given as the number of securing orders per tax subject. The number of issued 
securing orders in the monitored period is also analysed in relation to the total number of registered VAT payers.

Revenues (actual payment) from secured amounts are analysed in relation to the total amount of secured amounts. The result is given as the share of amounts actually paid from securing orders in the total amount of protected amounts (in percent). Revenues from reinsurance are subsequently analysed in relation to the total amount of value added tax collection. And the result is given as the share of revenues (actual reinsurance payments) in total VAT revenues in individual years of the observed period.

The evaluation of the effectiveness of securing orders is performed in terms of their profitability. The cost of issuing one securing order is estimated on the basis of wage and overhead costs recalculated per employee. The cost estimate is further based on the assumption that an average of three employees work on one securing order for 15 days. Revenues from one securing order were determined from the total number of issued securing orders and the total amount of reinsurance payments. The profitability of securing orders is then determined as the ratio of the income from one securing order and the cost of issuing it.

\section{Results and Discussion}

The number of issued securing orders was the lowest in 2014 in the monitored period. The analysis of the number of issued securing orders and the number of entities affected by a securing order shows that there is more than one securing order per tax entity (Table 2). Since 2017, there has been a partial slowdown in the issuance of securing orders in the financial administration. The reason was the debates of the general public about the possible risk of widespread misuse of securing orders by the financial administration, which were published during 2017 and 2018 by a wide range of different media.

Table 2. The number of issued securing orders in relation to the number of taxpayers affected by securing order. Financial Administration of the Czech Republic (2020), own processing.

\begin{tabular}{|c|c|c|c|c|c|}
\hline Number of issued securing orders & $\mathbf{2 0 1 4}$ & $\mathbf{2 0 1 5}$ & $\mathbf{2 0 1 6}$ & $\mathbf{2 0 1 7}$ & $\mathbf{2 0 1 8}$ \\
\hline Number of taxpayers affected by securing order & 1,032 & 1,605 & 1,561 & 1,420 & 1,174 \\
\hline $\begin{array}{c}\text { Number of securing orders per tax entity (affected } \\
\text { by the securing order) }\end{array}$ & 3.15 & 3.79 & 5.05 & 3.97 & 3.31 \\
\hline
\end{tabular}

The performed analysis of the number of tax subjects affected by the securing order shows that the issued securing orders concern a very narrow group of registered VAT payers. The share of entities affected by securing orders in the total number of all registered VAT payers is from $0.06 \%$ to $0.08 \%$. (Table 3 ).

Table 3. Share of the number of tax subjects with a securing order in the total number of VAT payers. Financial Administration of the Czech Republic (2020), own processing.

\begin{tabular}{|c|c|c|c|c|c|}
\hline & $\mathbf{2 0 1 4}$ & $\mathbf{2 0 1 5}$ & $\mathbf{2 0 1 6}$ & $\mathbf{2 0 1 7}$ & $\mathbf{2 0 1 8}$ \\
\hline $\begin{array}{c}\text { Number of VAT payers } \\
\text { Number of entities affected by the securing } \\
\text { order }\end{array}$ & 512,034 & 506,309 & 503,145 & 522,266 & 535,507 \\
\hline $\begin{array}{c}\text { Share of tax subjects concerned in the } \\
\text { number of VAT payers }\end{array}$ & $0.06 \%$ & $0,08 \%$ & 309 & 358 & 355 \\
\hline
\end{tabular}

The actual payment of the collateral is always lower than the protected amount. The share of reinsurance payments in the total secured amount increased from the original $6.14 \%$ to $43.29 \%$ in the period 2014-2017 (Table 4). Although the number of issued securing orders has been gradually decreasing since 2015 (Table 2), the amount actually 
reimbursed from reinsurance is increasing year-on-year, thus increasing the share of reimbursed amounts in the total amount secured. In 2018, the share of reinsurance payments decreased to $32 \%$.

Table 4. Share of payments in the total secured amount of securing orders. Financial Administration of the Czech Republic (2020), own processing.

\begin{tabular}{|c|c|c|c|c|c|}
\hline & $\mathbf{2 0 1 4}$ & $\mathbf{2 0 1 5}$ & $\mathbf{2 0 1 6}$ & $\mathbf{2 0 1 7}$ & $\mathbf{2 0 1 8}$ \\
\hline Amount secured (billion CZK) & 4.172 & 3.633 & 3.329 & 1.594 & 1.472 \\
\hline $\begin{array}{c}\text { Amount of payments from securing } \\
\text { orders (billion CZK) }\end{array}$ & 0.256 & 0.822 & 1.098 & 0.690 & 0.471 \\
\hline $\begin{array}{c}\text { Share of payments in the total secured } \\
\text { amount }\end{array}$ & $6.14 \%$ & $22.63 \%$ & $32.98 \%$ & $43.29 \%$ & $32.00 \%$ \\
\hline
\end{tabular}

The amount of payments from securing orders differs in individual years of the observed period. Revenue from securing orders in 2014 amounted to only CZK 256 million. In 2015 and 2016, there was a significant increase in payments from securing orders to more than CZK 1 billion. The average amount of revenue in the analysed period 2014-2018 is approximately CZK 800 million per year. In absolute terms, this is a large amount. However, the share in the total VAT collection is only $0.08-0.31 \%$ (Table 5).

Table 5. Share of payments in the total VAT collection of securing orders. Financial Administration of the Czech Republic (2020), own processing.

\begin{tabular}{|c|c|c|c|c|c|}
\hline & $\mathbf{2 0 1 4}$ & $\mathbf{2 0 1 5}$ & $\mathbf{2 0 1 6}$ & $\mathbf{2 0 1 7}$ & $\mathbf{2 0 1 8}$ \\
\hline $\begin{array}{c}\text { VAT collection (billion CZK) } \\
\text { Amount of payments from securing orders } \\
\text { (billion CZK) }\end{array}$ & 322.70 & 331.60 & 349.46 & 381.44 & 413.01 \\
\hline $\begin{array}{c}\text { Share of payments in the total VAT } \\
\text { collection }\end{array}$ & 0.256 & 0.822 & 1.098 & 0.690 & 0.471 \\
\hline \begin{tabular}{c} 
She \\
\hline
\end{tabular} & $0.25 \%$ & $0.31 \%$ & $0.18 \%$ & $0.11 \%$ \\
\hline
\end{tabular}

Further evaluation of securing orders was performed in terms of their profitability. Based on the analysis of wage costs per employee, it was found that the financial administration spent an average of CZK 34,114 per month per employee issuing securing orders in the period under review.

Overhead costs included in the calculation both the current costs of securing and work office aids for these employees and the use of relevant special licensed programs. These programs are necessary to analyse the financial and property situation of tax entities for which a securing order was assumed.

The performed analysis showed that the financial administration on average spent CZK 31,800 per month on one employee issuing securing orders for overhead costs. An estimate of the number of officials participating in the issuance of one securing order and an estimate of the time spent on the issuance of one securing order revealed and calculated that the financial administration had to spend an average of CZK 141,255 on issuing one securing order in 2014-2018.

Table 6. Wage and overhead costs of securing orders. Financial Administration of the Czech Republic (2020), own processing.

\begin{tabular}{|c|c|c|c|c|c|}
\hline & $\mathbf{2 0 1 4}$ & $\mathbf{2 0 1 5}$ & $\mathbf{2 0 1 6}$ & $\mathbf{2 0 1 7}$ & $\mathbf{2 0 1 8}$ \\
\hline $\begin{array}{c}\text { Monthly wage costs per 1 employee in } \\
\text { total (CZK) }\end{array}$ & 28,813 & 32,598 & 33,502 & 37,678 & 37,978 \\
\hline $\begin{array}{c}\text { Overhead costs per employee } \\
\text { total (CZK) }\end{array}$ & 31,700 & 31,750 & 31,800 & 31,850 & 31,900 \\
\hline $\begin{array}{c}\text { Total monthly costs (CZK) } \\
\text { conversion of total monthly } \\
\text { cost for 1 day (CZK) }\end{array}$ & 60,513 & 64,348 & 65,302 & 69,528 & 69,878 \\
\hline
\end{tabular}




\begin{tabular}{|l|l|l|l|l|l|} 
Cost of 1 securing order (CZK) & 129,690 & 137,880 & 139,950 & 148,995 & 149,760 \\
\hline
\end{tabular}

Profitability from securing orders is an important criterion for their evaluation. Revenues from one protection order were determined from the total number of issued protection orders and the total amount of reinsurance payments and are shown in Table 7 . In individual years of the observed period, the results are higher than 1. The issued protection orders are therefore effective in this respect (Table 7).

Table 7. Profitability of securing orders. Financial Administration of the Czech Republic (2020), own processing.

\begin{tabular}{|c|c|c|c|c|c|}
\hline & $\mathbf{2 0 1 4}$ & $\mathbf{2 0 1 5}$ & $\mathbf{2 0 1 6}$ & $\mathbf{2 0 1 7}$ & $\mathbf{2 0 1 8}$ \\
\hline Cost of one securing order (CZK) & 129,690 & 137,880 & 139,950 & 148,995 & 149,760 \\
\hline $\begin{array}{c}\text { Revenues from one securing order } \\
\text { (CZK) }\end{array}$ & 248,062 & 512,150 & 703,395 & 485,915 & 401,193 \\
\hline Revenues / costs & 1.91 & 3.71 & 5.03 & 3.26 & 2.68 \\
\hline
\end{tabular}

\section{Conclusion}

The instruments by which tax can be paid when paying taxes are the most important function. The securing order is one of the tools used by the Financial Office of the Czech Republic in the fight against VAT fraud. It is a tool that is used only in very specific cases and thus affects a very narrow and specific group of tax subjects.

. In the monitored period 2014-2018, 1,032 (in 2014) to 1,605 (in 2015) securing orders were issued annually. The issuance of securing orders involved an average of 355 tax entities per year. Most tax entities were affected by the protection order in 2015 (424 in total), while the least in 2016 (309). In the monitored period, there were always more securing orders per tax subject. The highest number of securing orders was found in 2015 and amounted to more than 5 per tax subject.

Revenues from securing orders in the monitored period 2014-2018 averaged CZK 800 million per year. On average, they accounted for only $0.18 \%$ of total VAT revenue. The actual payment from securing orders was assessed in relation to the total amount secured. It was found that an average of $27.41 \%$ of the amounts secured were paid.

The profitability of securing orders was determined by the share of the income from one securing order in the costs incurred per one securing order in the years $2014-2018$. The average value of profitability in the observed period was 3.3. Given that this value is higher than 1 , it can be stated that the securing orders issued by the financial administration in the years 2014 - 2018 were profitable. For the state budget, therefore, securing orders are clearly effective, because the yield from these orders is more than three times higher than the cost of issuing them.

The institute of the securing order contributes positively to the more effective fight against VAT evasion, but above all as part of the overall systemic measure of the Financial Administration of the Czech Republic. The evaluation of the performed analyses shows that this tool is effective primarily as a quality payment tool for the payment of tax that has not been paid. The securing order should find application globally.

This paper is a partial result of the research project No. 2019B0010 - Czech Social System Fraud Rate Estimation and System Optimization Proposals, supported by the Internal Grant Agency (IGA) of Faculty of Economics and Management, CULS Prague. 


\section{References}

1. Kliestik, T., Misankova, M., Valaskova, K., Svabova, L. (2018). Bankruptcy prevention: New effort to reflect on legal and social changes. Science and Engineering Ethics, 24(2), 791-803.

2. Jecminek, J., Moravec, L., Kukalova, G. (2020). Impact of aggressive tax planning on collection of income tax on legal entities. Politická Ekonomie, 68(1), 3-17.

3. Alm, J. (2019). What motivates tax compliance? Journal of Economic Surveys, 33(2), 353-388.

4. De Simone, L., Lester, R., Markle, K. (2020). Transparency and tax evasion: Evidence from the foreign account tax compliance act (FATCA). Journal of Accounting Research, 58(1), 105-153.

5. Kouba, T. (2016). The crime and the rationality in the area of tax evasions and tax arrears. Český finanční a účetní časopis, University of Economics, Prague, 2016(1), 83-97.

6. Stavjanova, J., (2018). Estimates of tax evasions in the czech republic based on analysis of non-observed economy. Politická Ekonomie, 66(5), 569-587.

7. Demir, B., Javorcik, B. (2020). Trade policy changes, tax evasion and Benford's law. Journal of Development Economics, 144, UNSP 102456.

8. Cristea, L.A., Voda, A.D., Ciocanea, B., Luca, M. (2020). Is the tax burden a generating factor of fiscal evasion in South-East Europe? Proceedings of the Conference on Economies of the Balkan and Eastern European Countries (pp. 153169). Bucharest.

9. Hoseini, M. (2020). Value-Added tax, input-output linkages and informality. Economica, 87(347), 813-843.

10. Moravec, L., Kukalova, G. (2014). Investments allocation tax factors in pre-crisis time. Proceeding of the 11th International Scientific Conference on European Financial Systems 2014 (pp. 396-402). Lednice.

11. van der Hel-van Dijk, L., Griffioen, M. (2016). Tackling VAT-fraud in Europe: A complicated international puzzle. Intertax, 44(4), 290-297.

12. Czechia. (2004). Zákon 235/2004 Sb., zákon o dani z přidané hodnoty. Retrieved from: https://businesscenter.podnikatel.cz/pravo/zakony/dph/.

13. Financial Office of the Czech Republic. (2020). Kontrolní hlášení DPH. Finanční správa. Retrieved from: https://www.financnisprava.cz/cs/dane/dane/dan-z-pridanehodnoty/kontrolni-hlaseni-DPH.

14. Balcar, V. (2017). Zajištovací př́kaz a dalši zajištovací instrumenty daňového řádu. Praha: C.H.Beck.

15. Balcar, V. (2019). Securing order. Financial Law Review, 15(3), 20-37.

16. Arltova, M., Pavel, J., Tepperova, J., Zidkova, H., (2020). what are effective measures against vat evasion? Evidence from the Czech Republic. Ekonomický Časopis, 68(2), 147-167.

17. Financial Office of the Czech Republic. (2020). Analýzy a statistiky. Finanční správa. Retrieved from : https://www.financnisprava.cz/cs/dane/analyzy-a-statistiky. 